\title{
Lexical Asymmetry as a Translation Problem Arising in the Holy Quran
}

\author{
Emad Ahmed Al-Tamari \\ English Department, Faculty of Languages and Translation, King Khalid University, Abha, \\ Kingdom of Saudi Arabia \\ Eyhab Abdulrazak Bader Eddin \\ English Department, Faculty of Languages and Translation, King Khalid University, Abha, \\ Kingdom of Saudi Arabia \\ Corresponding Author: linguisteyhab@hotmail.com
}

Received: 4/12/2021

Accepted: 5/11/2021

Published:5/24/2021

\begin{abstract}
Coupled with copious evidence and cogent illustrations, this article charts an important development in the field of translating the Holy Quran. It breaks new ground in a new type of problems inherent in the translation of the Quran. It is designed to catch translators' alert senses to look beyond the traditional approach to translation, i.e. looking for the superficial equivalent. It critically discusses the long-standing proclivity for the deeply-held belief in the existence of absolute synonyms in the Quran. Although the examples given are not very exhaustive due to space constraints, the author's unbridled reason pushes him to how far semantic propinquity exists in the Quran, developing a plethora of new checklists which will definitely act as a springboard to lay groundwork to any translator. The paper draws a conclusion that the seemingly verb and noun synonyms in the Quran are not so, resulting in a lexical asymmetry in translation. This paper zooms in on a new type of sense relationships, which involve a pair of words with similar meaning, but are made up of the same root morphologically. The paper takes three very popular and mesmerizing translations of the Quran as a point of reference. This paper shatters the fervent belief that one word can be a full equivalent to seemingly synonymous words in the Quran. This is a strong call on translators to start looking at new issues in the translation of the Quran from different standpoints, an arresting fact we need to grasp.
\end{abstract}

Keywords: Quran translation, lexical asymmetry, synonyms, translation problem

Cite as: Al-Tamari, E. A., \& Bader Eddin, E. A. (2021). Lexical Asymmetry as a Translation Problem Arising in the Holy Quran. Arab World English Journal for Translation \& Literary 


\section{Studies 5 (2)2-17. DOI: http://dx.doi.org/10.24093/awejtls/vol5no2.1}

\section{Introduction}

Language has always been a never-ending topic which has preoccupied linguists, philosophers and psychologists for years and proved a fertile soil for writing on, probably one reason why books on language are still written. Not getting deeply immersed in the details of the difference between the human language system and what some may refer to as 'animal communication system', we will confine ourselves here to human language. Language is a humanity-characterizing attribute, which draws a line between humans and non-humans. This is true to the extent that some people in Africa call a newborn child a 'kintu', literal for 'a thing'. Once that 'kintu' starts to possess a language, s/he is called 'a muntu', literal for 'a person' (Fromkin, Rodman and Hyams., 2007). Language is so close to ourselves exactly as any other vital activity like breathing. Scarcely can a moment of our waking life be lived without words, even in our dreams, let alone the phenomenon of somniloquy. Perhaps this has driven Chomsky to refer to language as 'human essence' (Chomsky, 1972) and Sapir (1921) as 'purely human'. In the Holy Quran, we have an explicit mention made of how 'abstention' from using language is hard and is considered a yardstick to gauge one's commitment to Allah's orders. In the Chapter of Mariam,

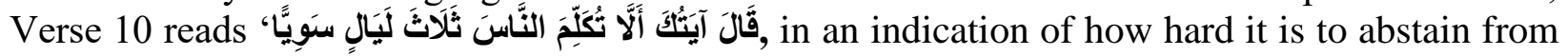
talking to people.

Translation is as old as language itself when different civilizations come into contact. Translation has always been the magical tool through which any communication barriers are broken down. It is a complex process by means of which its operator is required to transfer the same natural equivalent of the source text language into the target text language. Translation involves code-deciphering of the verbal signs of the source text and re-coding it in the target text. Translating, in one sense, is the process of decoding the source language text, and rendering it into an equivalent in the target source text on the semantic, syntactic and pragmatic levels (Bassnett, 1996). Translators may find themselves on a chase and in pursuit of equivalents, and end up with as a close text as possible to the source text. This pursuit might take on a sense of ambiguity that threatens to cloud rather than illuminate the process of translation. The authors, personally, believe that any act of understanding is -in one way or another- a form of translation whether explicitly expressed as visible traces on paper addressing eyes, or expressed as vocal movements in the form of sound waves, addressing ears. The former is generally referred to as 'translation', whereas the latter is referred to as 'interpreting'. When speech is responded to in the same language, providing answers, this is called 'communication', but when the same message in the source language is reformulated or re-echoed in another language, it is called 'translation'. Thus, any attempt of understanding is actually an attempt of translating (Jasper, 1993).

Translation has always involved diction, i.e. word choice. This word choice is supposed to be the exact equivalent to the meaning in the source text. Exact or absolute equivalence between the source and target texts has been a heated debate, sparked off by translation practitioners. One sound argument states that a multiplicity of words might be used in Arabic to refer to a concept which is often referred to in English in one word, rejecting the claim that says there is always a one-to-one relationship between any pair of languages. This shows how the two languages strikingly look at the same thing in different manners. Philosophically tendentious, Translation is 
more concerned with the presupposition of homogeneity (Lyons, 1981). This means referring to things is often 'similar' rather than identical. This calls into question the actual existence of synonymy. Dearth of complete synonyms has generated 'asymmetry', i.e. incongruity between source and target texts at the lexical level. This paper is an in-depth investigation of a translation problem, embedded in linguistics, i.e. lexical asymmetry. Lexical asymmetry is one of the most slippery concepts in linguistics in general, and in translation in particular. Lexical asymmetry is a new type of sense relationships among pairs of words whose root is morphologically the same. Synonymy usually involves the relative degree of sameness in meaning, most often realized in words whose root is different morphologically. One illustrative example of the former is اسطاعوا

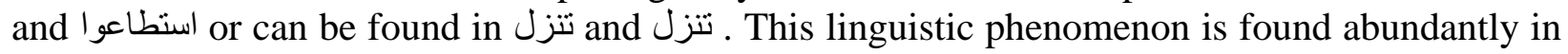
Arabic whereas it is rare if not existent altogether in English due to the reluctance of the English morphology to accept manipulations of inflections like Arabic or even Latin whose one verb is prone to accept one of 120 inflections (Bryson, 1990). On the other hand, an example of synonymy is found in 'fast', 'quick', 'swift' and 'rapid'. This study sheds lights on a text, no less than the Holy Quran, the cynosure of all eyes in terms of Arabic linguistic excellence. The paper discusses the failure of English to capture all the subtleties of the seemingly synonymous words in the Quran. It shows the inadequacy of English to find out specific designations to the Arabic lexis used in the Quran. This leads to the failure on the part of the Quran's translators, many of whom are unaware of the overtones and shadows of semantics, lost when using the same word for two seemingly synonyms in Arabic. In the following sections, the researchers try to provide answers to the following probing questions:

Are lexical and morphological forms which seem synonymous meant to mean exactly the same? Does each letter count in the Quran, morphologically and semantically speaking?

Are there absolute synonyms of seemingly synonymous words in the Quran? Are they interchangeable in meaning, and thus one target text word could be used to refer to all the source text words exactly?

\section{Literature Review}

It is hard to close our eyes to the degree of lexical symmetry between the meaning of words in source and target texts. Perhaps this is one fundamental parameter, which is relied on to pass a judgement on a translation, in addition to other factors related to syntax, stylistics, phonology in sound-sensitive texts, pragmatics, culture, etc. Meaning of words includes different sense relationships, i.e. synonymy, antonymy, polysemy, hyponymy, etc. One may find out that 'equivalents' between a pair of languages and 'senses' within one language display a network of similarities, and the more they share of the semantic properties, the more they are said to be 'synonymous'. This linguistic area becomes more and more complicated across languages due to other factors such as language history, word etymology, usage, range of senses, etc. It is worth mentioning that 'synonymy' is a sense relation which holds within one language, whereas 'equivalence' involves dealing with at least two languages. Equivalence does not necessarily follow the rigid formula of one-to-one relationship.

Semanticists fall into two camps: those who advocate synonymy and those who oppose it. Objectionists to 'synonymy' claim that there is no need for more than one word in the same 
language to refer to the same concept or thing. Based on Ogden and Richard's classic treatise published in 1923 (Meaning of Meaning), Lyons (1977) gave us a very interesting principle for establishing 'equivalents' or 'at least 'close equivalents'. Ogden and Richard's (1923) principle read "Symbols which can be substituted one for another symbolize the same reference". He proposed a substitution-based principle, i.e. if the word $\mathrm{X}$ fits to be substituted by another word, it is said in this case that the words ' $\mathrm{X}$ ' and ' $\mathrm{Y}$ ' are equivalent or synonymous. Otherwise, they are not. One example for illustration is "I did not mean to hurt you". The italicized word can be substituted by 'intend' without really affecting the meaning. Therefore, the word 'intend' and 'mean' are equivalents in this particular context while they might not be in other contexts. No matter how words look synonymous, there are differences which could be dialectal, stylistic, collocational or emotive (Crystal, 2010). On the same wavelength are Ogden and Richards (1923) who did not believe in the existence of 'complete synonyms' as opposed to 'partial synonyms' which are common. Al-Askari (2015) said that no two words should be referring to the same meaning or sharing the same sense because this proves the existence of redundant futile lexical duplication.

Because "the meaning of a sentence is the product of both lexical and grammatical meaning" (Lyons, 1981), scholars cannot overlook the interchangeability of seemingly synonymous words. In other words, it is important to reflect on using the same word in English for two different words in Arabic. Our focus here is the Holy Quran and its translations. The Quran has always been a model of linguistic excellence whose style is described as 'sui generis'. Its uniqueness stems from the fact that it is Allah's very Word, revealed to His Prophet Mohammed (PBUH). The Arabic language of the Holy Quran is classical Arabic.

It is known that classical Arabic is famous for possessing scores of names for the different parts and details of fire sounds, types of rain, dust types despite the rarity of use of such examples. Arabic outnumbers English in being more specific whereas English cannot but be 'general' with such respects. Below is an example of the exact designations Arabic gives to the sound uttered by a horse in different situations. However, English is limited to one word in reference to the cry uttered by a horse, i.e. 'neigh'.

Table 1. Various sounds uttered by horses

\begin{tabular}{|c|c|c|c|c|}
\hline صوت بطنه & طلب العمة: صوته أو رأى & 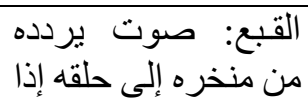 & إذا عدبح: صوت نَفَسها & الفرسهيل: عموماً صوت \\
\hline $\begin{array}{l}\text { The sound } \\
\text { produced at the } \\
\text { horse's stomach } \\
\text { as lurching. }\end{array}$ & $\begin{array}{l}\text { صاحبه فاستأنس إليه } \\
\text { The horse's } \\
\text { sound when } \\
\text { hungry or when } \\
\text { it sees its hostler }\end{array}$ & $\begin{array}{l}\text { نفر من شيء أو كر هـ } \\
\text { The horse's } \\
\text { sound to express } \\
\text { its dismay at } \\
\text { something }\end{array}$ & $\begin{array}{l}\text { The horse's } \\
\text { sound when } \\
\text { galloping }\end{array}$ & $\begin{array}{l}\text { The sound } \\
\text { uttered by horses } \\
\text { in general }\end{array}$ \\
\hline
\end{tabular}

Note 1. Adapted from Al Tha'alibi (2001, P. 115)

Zipf (1965) attributes English not having too specific designations to the insufficient frequency of occurrence. He argues that nothing prevents English as a language from having a specific designation for 'a person's uncle's second wife's tenth child', but it is not there in practice. 
There is a direct relationship between a certain word coinage and its importance in language. He goes further to say that when an object or concept is felt to be important, the language in question puts concerted efforts or feels the need to create or coin a new lexical item reflecting it. The example "German" (schadenfreude) whose exact equivalent is missing in English is a case in point to the extent where it becomes a loan word in English in the early twenties of the past century. Similarly, (الغبطة) joy and happiness for someone else without envying them or wishing that they would lose the good points they have) misses its counterpart in English. In English, there is no word which encompasses both 'joy and happiness for someone else' and 'not envying them'. Usually, it is either 'one feels happy for someone' or one does not envy them'.

As discussed above, every language classifies physical reality in its own way. It is worth me ntioning here that English uses 'foot' to denote the extremity of the leg whereas in Russia there is no equivalent for 'foot'. Instead, the word 'noga' denotes the whole leg including the foot (Wilkins, 1972). By the same token, English operates with only one word for 'sand', whereas Arabic uses several words to denote different types of sand (Caroll, 1963, as cited in Wilkins, 1972). An example is given below:

Table 2. Names used in reference to various types of 'dust'.

\begin{tabular}{|c|c|c|c|c|c|}
\hline $\begin{array}{l}\text { العفاء: التراب الآني } \\
\text { ليدرس الآثار } \\
\text { Dust effacing } \\
\text { traces }\end{array}$ & 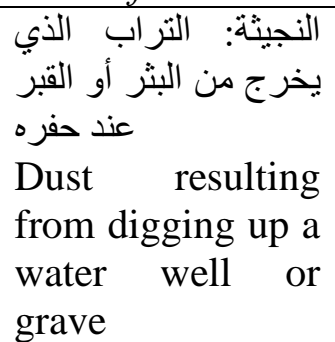 & 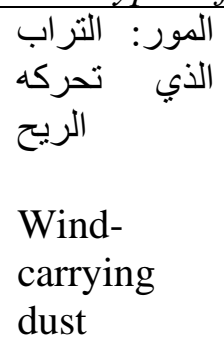 & 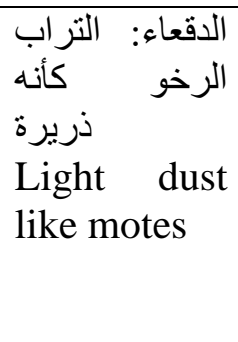 & $\begin{array}{l}\text { الثرى: الترابي } \\
\text { Wet dust }\end{array}$ & الصعيد: \\
\hline \multicolumn{3}{|c|}{$\begin{array}{l}\text { السماد: تراب مختلط بالأقذار لتخصيب التربة } \\
\text { Dust mixed with dung used as a fertilizer }\end{array}$} & \multicolumn{3}{|c|}{$\begin{array}{l}\text { الرغام: التراب المختلط بالرمل } \\
\text { Dust mixed with sand }\end{array}$} \\
\hline
\end{tabular}

Note 2. Adapted from Al-Tha'alibi (2001, p. 149)

\section{The Holy Quran translation history}

The Quran is the very Word of Allah, revealed to prophet Mohammed (PBUH) through Angel Gabriel as a message direct from Allah. It is the sacred scripture of Islam, divided into 114 chapters called suras which observe no chronological order. On the contrary, the ordering of the suras is roughly in descending order of length (France, 2000). The Quran is the fundamental and paramount source of the creed, rituals, ethics, and laws of the Islamic religion. This supreme status stems from the belief that the Quran is the Word of God, revealed to the Prophet Muhammad via the archangel Gabriel, and intended for all times and all places (Abdel Haleem, 2008). The matchless Arab literary characteristics of the Quran remain formidable obstacles to translation. The Quran was the first prose book in Arabic and has remained the model of excellence for Arabic literature. It has been seen by literary critics of the Arabic language as artistically unequalled in its beauty. It was committed to writing on palm fronds, leather, stones or such other rude material as conveniently came to hand (Nicholson, 2008). 
The Holy Quran has been translated into most of the languages of Europe, Asia and Africa. It was Robert of Ketton who produced the first translation of the Quran into a European language (Latin) in Spain in 1143, but was not published until 1543 in Basel. Alexander Ross translated the Quran into English but from a French version in 1649. It was George Sale who produced the first translation into English, directly from an Arabic version in 1734 (France, 2000). To date, there have been over 30 translations of the Quran into English by Muslims, the first of which was done by the Rev. Rodwell in 1861. The most popular translation is that of Abdullah Yusuf Ali. Almost all of the translations produced by Muslims were done by translators from the Indian subcontinent.

\section{Methods}

The approach taken here is selective analytical. Appropriate examples from the Holy Quran have been selected. These examples are explained and analyzed in the light of the underlying assumptions of the paper. There have been no firm dividing lines between what many consider to be as 'complete synonyms'. Due to constraints of space, The authors have limited myself to a few examples. The examples selected will be compared with their translations by three popular translators, i.e. Ali, Al Helali et al and Pickthall. The reasons for not accepting their translation will be demonstrated. One tabulation will be included in the appendix to vividly demonstrate the original text, with the three different translations. By careful scrutiny, The researchers had delved into dealing with what appear to be verb and noun synonyms.

\section{Discussion and Analysis}

One chief concern of a competent translator should be deciding what the source text actually means even before jotting down the translation. This means a translator needs to keep pondering over each string of words, and ask himself/herself 'what is exactly meant'? 'Does this make any difference if translated otherwise'?, etc. Advocating the claim that no absolute synonyms ever exist brings about a very crucial question: Why do different translators come up with different translations for the same source text? The answer to this question is that each translator has different linguistic schemata which make the translator feel that certain words have more resemblance to a source text word than others do, creating the various range of used words as equivalents to certain words in the source text.

Contrary to the reasonable expectations that synonyms are in complementary distribution, Cruse (1995) clarifies it by saying that 'kill' is listed as a synonym to 'murder, but more interestingly NOT vice versa. However, he goes further to say that certain words are more 'synonymous' than others. One example is that 'settee' and 'sofa' are more synonymous than 'die' and 'kick the bucket'. Therefore, it is inferred that synonyms share the central semantic properties, but differ in the peripheral traits (Cruse, 1995). The more they overlap, the more synonymous they are. One example from Arabic might be the following nouns which are degrees of 'shortness' of a man:

Table 3. Names given to describe degrees of man's shortness

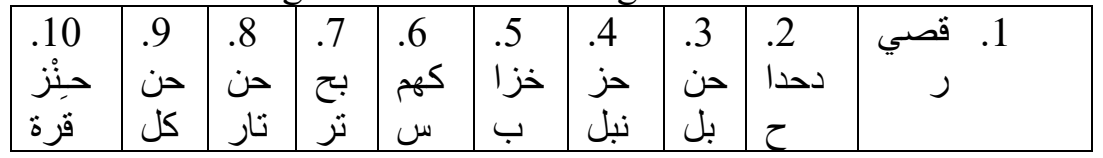

Arab World English Journal for Translation \& Literary Studies

ISSN: 2550-1542 | www.awej-tls.org 
All of the above-listed nouns share the central semantic property of 'shortness', but differ in the 'degree' of that shortness from one person to another.

Our focus of attention in this paper is discussing whether 'seemingly' synonymous words in the Holy Quran are swappable or not. The seemingly synonyms in the Holy Quran invite comparison and analysis. Most translators do not show any sense of spotting any difference between each pair of seemingly synonyms in the Holy Quran, making them swap one word with another. The analysis will show the asymmetry brought between the synonyms in translation. Hervey and Higgins (1992) stress that translation involves a translation loss, not loss of translation, but a loss in the translation. So, an inevitable loss is suffered despite the serious attempt to do full justice to the depth of the source text.

An attempt will be made to examine Bloomfield's hypothesis as a point of departure. In his seminal book, Bloomfield (1933) states that if the forms are phonemically different, it is supposed that their meanings are accordingly different. It echoes the Arabic morphological rule that reads زيادة في المبنى زيادة في المعنى (Samirraei, 2000). The problems associated with the morphology of the source text, i.e. Arabic, have been one major concern of translators. This is because of the complexity of Arabic morphology which is similar to Latin in terms of productivity of word formation from the same root. In his classical treatise on language, Bloomfield (1933) argues that if the forms are phonemically different, their meanings are supposedly also different.

In the Holy Quran, we notice that mention is made of many words which are seemingly synonymous and thus swappable, to the extent that the Quran translators have dealt with those pairs of words alike, on equal footing because they believe they carry no semantic change and accordingly they are symmetric. The following sections will be designed to explore this area by first shedding light on verbs and then on nouns.

\subsection{Seemingly Absolute Verb Synonyms}

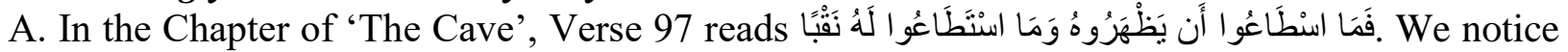

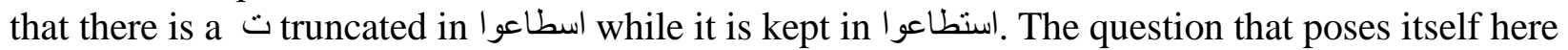
'does that make any difference in meaning'? 'Are the two forms of the same root verb swappable and thus can be interchangeably used?' 'Is the translation correct to use the same verb or structure pattern to render them'? Did the 3 translators succeed in spotting the semantic difference, brought by the truncation of $ت$ ?

Taking the linguistic rule stated above by Bloomfield (1933), and reiterated by Samirraei (2000), a truncation of certain letter(s) indicates a shorter, easier or less laborious action. By the same token, keeping or adding the truncated letter(s) reflects a longer or harder action. Exegetes unanimously state that اسطاعو I is mentioned in reference to climbing or jumping over the great wall while استطاعوا is mentioned in reference to boring or digging through it. It is crystal clear that the first action is easier than the second, making the truncation of $ت$ commensurate with the amount of effort needed in comparison with the action of boring the wall. So, keeping the $ت$ as an infix indicates a more laborious work, compared to climbing it, a relatively easier task reflected by the truncation of $ت$ (Al Ghirnati, 1985). 
Having a look at the table in the Appendix demonstrates how the three translators are not aware of the analysis provided above. They consider both verbs alike, and thus join them with a coordinating conjunction, i.e. 'or' (Ali, 1992; Khan, M. M., \& Al Helali, 1994) while Pickthall (1999) uses 'nor' without a preceding 'neither' as an archaic use of the correlative conjunction 'neither... nor'. The three translations show no meticulous understanding of the difference between the two forms of the verb. In this light, this reveals that swapping the two verbs with each other would reflect asymmetry, and imbalance between the semantic message conveyed and the form of the verb suitable to carry that message.

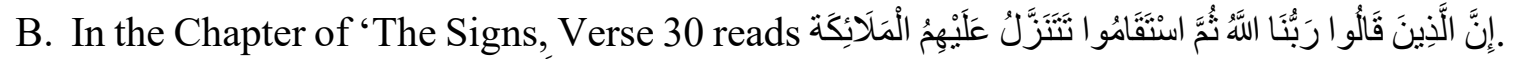

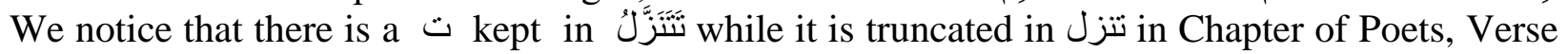
221 (see the appendix). The three translators pay no attention to the existence or truncation of the $ت$. All of them translate the verb as 'to descend'. However, the truncation and inflection of the $ت$ is carefully carried out, with a different semantic message resulting in each case. The inflection of $ت$ in the former verse listed above is significant because it indicates the large number of angels descending on believers on death to announce to them that the Paradise is their reward for the good deeds they did in their lives (Al-Shawkani, 1929; Al-Alusi, 1847). This act occurs more as death happens every second, and there must be believers at those moments around the clock across the world. However, in the second verse, the $ت$ is truncated because the context of situation indicates that the devils do not descend on all the disbelievers; rather this action is limited to part of the disbelievers who are described as كل أفّاك أثنم يلقون السمع at a specific period of time during the Prophet's time. So, the truncation of $ت$ is associated with the less number of angels and the action which is less frequent in occurrence.

One more example, supporting this argument comes from the Chapter of 'Power'. Verse 4 reads تنزّل الملائكة والروح فيها. The reason why the تis truncated is that the angels descend only at this blessed night which occurs once a year. So, the truncation is associated with the rarity of the setting of that particular night at Ramadan.

C. The last example cited from the Holy Quran which has received little attention on the

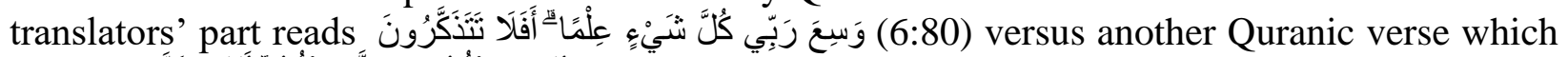

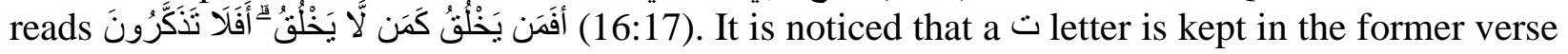
whereas it is truncated in the latter one. It is also noticed that the three translators deal with both alike, spotting no difference in both as shown in the appendix. The translations made show their translators never distinguish between the two verbs in the two Quranic verses. They can see no clear boundary between the existence and truncation of $\rightarrow$ in initial position.

Moving on to the context of situation which saw the first Quranic verse, it is Messenger Ibrahim as a bitter heated argument erupts between him and his polytheist people. The reason $ت$ is inflected to the verb is that Ibrahim's journey was arduous until he eventually established the absolute truth of the existence of Allah, having had to pass through many stages of getting to know the Deity worth being worshipped. He started to think that the deity to worship was the planet, then the sun until he knew that the only Deity is Allah after deep and careful contemplation. So, the inflection of the $\vec{\sim}$ is associated with the long difficult journey of discovering the truth, 
brushing aside astrolatry. So, the $ت$ suggests longer and arduous efforts to discover the truth. However, in the second verse it is self-evident and crystal clear for any lay man that there is a difference between the sighted and the blind. So, the truncation of the $ت$ is associated with finding a quick answer to a simple question, i.e. (the seer and the blind are not alike).

\section{Seemingly Absolute Noun Synonyms}

A. This section is dedicated to discussing the lexical asymmetry in the translation of some nouns mentioned in the Quran, and the inevitable loss inherent. It might have escaped the notice of many translators that the epithet associated with 'date trees' is used once in the masculine form (54:20), and once in the feminine form (69:7). More importantly and interestingly, none has paused to ponder over if the masculine and feminine adjectives منقعر وخاوية modifying the same noun أعجاز نظhave any effect on the semantic message. Such a feature in the source text is salient, but translators are unaware of that effect on the meaning.

Arabic grammarians have mentioned that the Arabs tend to use 'feminine' inflections or epithets to indicate 'abundance, whereas they tend to use 'masculine' inflections or epithets to

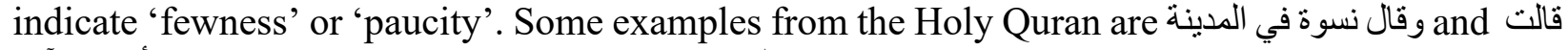
الأعراب آمنا. In the two examples given here, النسوة (which is definitely a feminine noun) is preceded by a verb in the masculine form to indicate they were few in number. However, الأعراب (which is definitely a masculine noun) is preceded by a verb in the feminine form to indicate they were many in number (Al Farra, 1955). Some nouns accept feminine $ت$ to indicate 'hyperbole', as in نابغة or (Ibn Yaeesh, 2001; Al-Sayouti, 1907). The hyperbole-indicating ت داهية is referred to as a metaphoric $ت$ because it is not associated only with feminine nouns. On the other hand, a linguistic rule reads 'description by singular indicates abundance' and 'description by plural indicates paucity'. An illustrative example is أشجار مثمر اتwhich indicates that the trees are few, as opposed to أنشجار مثمرة which indicates that the trees in focus are many (Samirraei, 2006).

Based on the above introduction, we find out that the palm trees mentioned in the verse are more than those mentioned in the verse كأنهم أعجاز نخل خاوية is supported by the following points:

- The wind mentioned in the verse including كأنهم أعجاز نذل خاوية is given a longer description

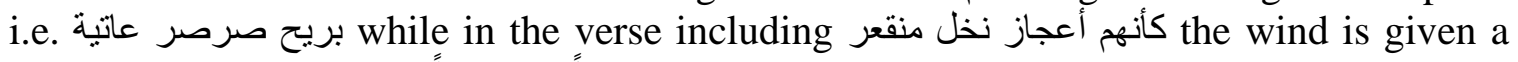
shorter description, i.e. ريحاً صرصراً. The longer description indicates a fiercer wind sweeping through the people, naturally reflecting the number of the trees uprooted were more, in association with the wind described in greater detail.

- In the verse including كأنهم أعجاز نخل خاوية, the duration of the wind is much longer than that when كأنهم أعجاز نخل منقعر is mentioned, in addition to the intensity of the wind. In the first verse, the duration is explicitly mentioned as سخر ها عليهم سبع ليال وثمانية أيام حسوما while the duration of the wind in the second verse is stated as في يوم نحس مستمر ليام wind indicates the amount of destruction. By logic, the longer the duration of the wind, the more destruction takes place.

- An emphasis of the degree of annihilation is mentioned in the first verse, i.e. فهل ترى لهم من باقية Here, means 'no'. This emphasis is not mentioned in the second verse, showing 
further that the wind in the first verse is fiercer. All the above-mentioned factors make using خنقعر indicate more trees were uprooted. This semantic message is not spotted in the translation, nor is any understanding of the status quo manifest through the translation. So, exchanging the epithets with each other would create an imbalance in the depicted logical picture of the scene. More importantly, such a salient feature is not reflected in the translation.

B. Elaborating further on seemingly synonyms, and whether the Quran's choice of words is meticulously selected or not, let us bring into focus the words أجداث and قبور in the Holy Quran. Translators do not seem to have reflected on whether any difference can be spotted, making them use the same word in English for both, i.e. graves. The word أجداث appears three times, while القبور appears five times throughout the Holy Quran. Both lexical items have the same referential meaning in Arabic. Perhaps that is why translators view them both alike, and consequently use the same word for both in English.

Interestingly enough, the Holy Quran uses them meticulously and with infinite accuracy. Etymologically, the singular of جداث the ward جدثة pelongs to Arabic means the sound of friction of animal hooves against the soil they walk on, and it also means the sound of munching on flesh in an explicit reference to the sound probably uttered when the flesh of the bodies of the dead is decomposed in their graves (Al Fairouzabadi, 2008). Here stems a very interesting unique use of the word أجداث, which is not found in the use of القبور (see Appendix A). The word appears in the Quran only when a picture of motion of the dead is given, as the dead rush for the Assembly Day for the Judgement Day after resurrection. Note the three verses

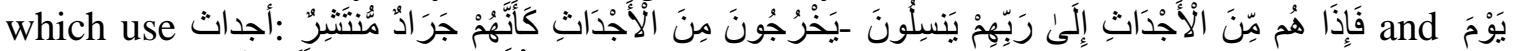

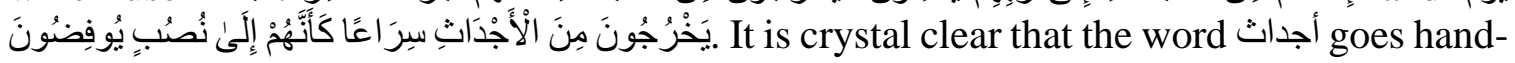
in-hand only with the scenes where the dead are brought to life, and rush for the Judgement Day. The word أجداث is used in this particular context of situation as if it intends to tell us that the sound they produce as rushing is like the sound of the friction, produced as animal hooves walk after the flesh of those bodies are munched on in their graves. Keeping these details helps conjure up a full accurate picture of how the scene unfolds, creating an audiovisual picture. In the translations provided by the 3 translators in question, it is found out that their translations deal with both قبور alike.

On the other hand, the lexical item القبور never appears where أجداث does in the Holy Quran. The word القبور is held through the Quran in contexts of situation where the dead in their dormant status are the focus of attention. The dead are shed light on as motionless

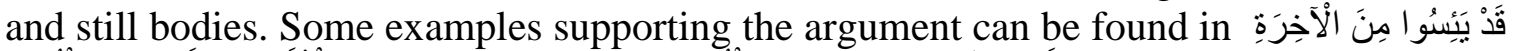

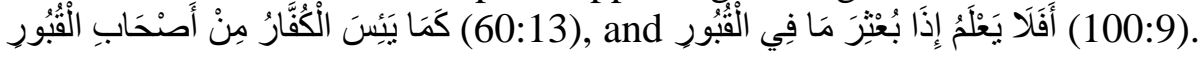

C. The last example showing the uniqueness of vocabulary usage in the Holy Quran is the usage of the words رياح which both have received very little attention by translators. The two words are usually translated as 'winds', sometimes modified with certain epithets, but the head of the relevant noun phrases is always 'winds'. The word الرياح in the nominative case appears 10 
times in the Quran, whereas الريح in nominative, accusative and dative cases appear 18 times, one of which carries the meaning of 'smell' in the Chapter of Yusuf (12:94).

The matchless stylistic usage of the Holy Quran limits using الرياح to glad-tidings-bringing contexts of situation whereas الريحited to contexts of situations, characterized by chastisement and events with dire consequences (Al Jahiz, 2010). Some of the examples proving

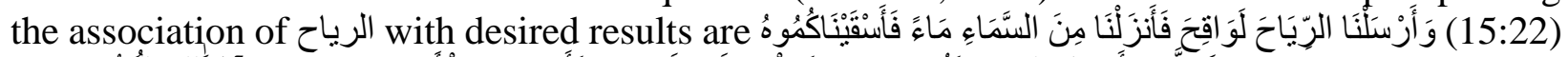

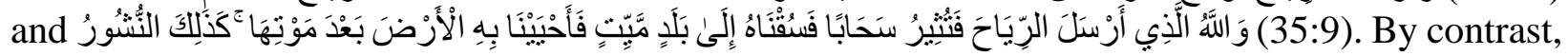
the usage of الريح is always associated with disastrous consequences as shown in the following

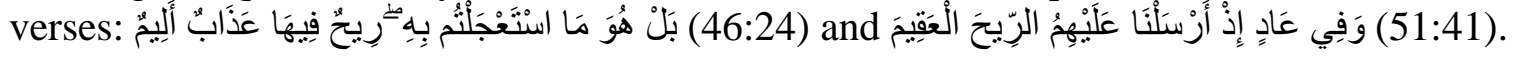

One striking exception to the rule stated above is found in:

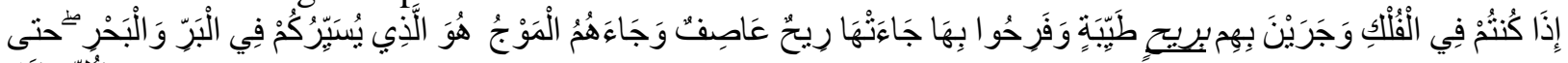
ريح is described as 'fair' and 'moderate' is that 'one wind' in the singular is needed to push the sails of a ship to carry on smoothly in the sea. In case a plural form of wind was used, then the ship would not have set sail smoothly. It is important that this short scene is immediately followed by a tragic event as shown in the verse as reading

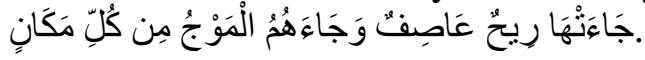

As Appendix A shows, the three translators never distinguish between the positive and negative connotations, linked to the usage of the two words in focus. They view the two words from the same perspective, spotting no difference in the semantics of the two senses carried over by each of the words. By the same token, the Holy Quran uses البحر and many people believe they are interchangeable and thus in free complementary distribution. The three translations of both words are the same (see the appendix). This shows that the translators in question understand the two words alike.

However, the two words appear in a unique way in the Holy Quran. The word البحر is used generally in the Quran including but not limited to Moses' story and the sea as a bliss and a source of fish and jewels, etc. The word البحر appears 33 times throughout the Holy Quran in general contexts. By contrast, the word اليج appears 8 times and only in horror and fright contexts of

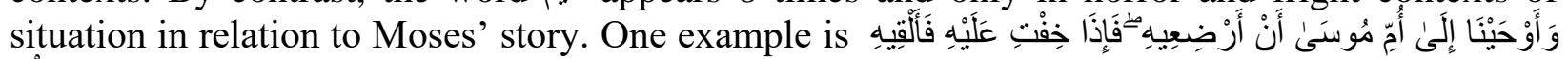
اليم has its etymological roots in Syriac and Hebrew, the latter of which Moses spoke as an Israelite. So, the word اليج particularly used in the contexts of situation revolving around Moses.

The translators have shown (see the appendix) no sensitivity regarding what each word reflects in the Holy Quran. So, the usage of اليح is intentionally associated with Moses who spoke that language. The Quran includes no complete synonyms which can be used interchangeably. The style must be described as 'sui generis', whose matchless expressions make up an enormous challenge that has long been rising to the translators.

\section{Conclusion}

Arab World English Journal for Translation \& Literary Studies 
Exuberant flows of new translations of the Holy Quran is a daunting task which will keep in existence every time a new reading of the Holy Quran is developed at all levels: linguistic, stylistic, morphological, semantic, phonological, etc. One can but- in vain- wishes that a perfect translation sees light one day. The translations made so far have been misty in stark contrast to the high expectations of producing a perfect translation one day. It transpires that missing any aspect of proficiency at translation would wash away meaning.

It has been found out above that coming up with a symmetry of the source text is an issue far from being settled. Persistent, lexical asymmetry has insisted on imposing the final say regarding the translation of the Holy Quran. It is a misnomer to believe that the Quran is fraught with repetitions in the form of 'complete synonyms', a formidable challenge which has faced translators for decades. In this paper, the authors did their best to plug away at exploring a rarelytrodden path and uncharted territory of the problems inherent in translating the Quran. Each word in the Holy Quran is meticulously selected, and accepts no replacement with any seemingly synonyms. The authors would not be exaggerating to say that each letter in the Quran counts in position and in sound.

\title{
Acknowledgments
}

The authors extend their appreciation to the Deanship of Scientific Research at King Khalid University for funding this work through General Research Project under grant number (GRP190-41/2020).

\begin{abstract}
About the Author
Dr. Emad Ahmed Al-Tamari is an Assistant Professor of Linguistics at the Faculty of Languages and Translation at King Khalid University, Abha, Saudi Arabia. He earned his Ph.D. in Linguistics from the University of Kansas, USA. His major is Syntax. Other areas of interest include syntaxsemantics interface and second language acquisition. https://orcid.org/0000-0002-0121-2166
\end{abstract}

Eyhab A. Bader Eddin, BA, MA, PhD, CL, MCIL, MITI is an Assistant Professor of Translation at King Khalid University, Abha, Saudi Arabia. He has an extensive teaching experience in such countries as Syria, Oman, Kuwait and Saudi Arabia. Dr Bader Eddin has been teaching exclusively on the MA programme for the recent 4 years. With a PhD titled Semantic Problems in A. J. Arberry's Translation of the Suspended Odes (Mu'allaqat), Dr Bader Eddin is passionately interested in Classical Arabic and how it can be functionally translated into English. He has published extensively in the fields of linguistics and translation in such refereed journals as Translation Journal, the British Journal of Middle Eastern Studies, etc. Dr Bader Eddin's research interests include, but are not limited to, theory of translation, translation competence, literary translation, stylistics, translation training, systemic linguistics, discourse analysis and the salient features of the Gracious Quran in translation. https://orcid.org/0000-0003-0096-6334 


\section{References}

Abdel Haleem, M. (2008). The Qur'an: A new translation. Oxford: Oxford University Press.

Al Fairouzabadi, M. (2008). Al qamous Al muheet [The Comprehensive Dictionary]. Cairo: Dar Al hadeeth.

Al Farra', A. (1955). Ma'ani Al Quran \{Meanings of the Quran]. Cairo: Dar Al kutub Al Masriya lil ta'leef wa Attarjama.

Al Ghirnati, A. (1985). Malak Atta'weel El Qate' bi zawi Al Ilhad wa Atta'teel [The sharp Complete Exegesis Confronting the Atheists]. Beirut: Dar Annahda Al Arabiya lil tiba'a wa annashr.

Al-Alusi, S. (1847). Rouh Al-ma'ani fi tafsir Al-Quran Al-atheem [Spirit of meaning in the exegesis of the holy Quran]. Beirut: Dar Ihiaa Atturath Al-Arabi.

Al-Askari, A. (2015). Al Furouq Al lughawiyah [The Linguistic Differences]. Beirut: Dar El Kutub El Ilmiyah.

Ali, A. Y. (1992). The Meaning of the Holy Quran. Maryland: Amana Corporation.

Al-Jahiz, A. (2010). Al Bayan wa Al Tabieen [Clarification and elucidation]. Cairo: Maktabat Ibn Sinaa.

Al-Sayouti, J. (1907). Ham 'ul Hawame' [Tears of the Tearful]. Cairo: Matba'at Assa'adah.

Al-Shawkani, M. (1929). Fathul Qadeer [Conquest of the Almighty]. Cairo: Matba'at Mustapha Al baby Al Halabi wa Awladuh.

Al-Thalibi, A. (2001). Fiqh Al-lugha wa Sirr al-Arabiya [Arabic philology and Secret of Arabic]. Beirut: Al Maktaba Al-Asriya.

Bassnett, S. (1996). Translation Studies. London: Routledge

Bloomfield, L. (1933). Language. Holt, Rinehart \& Winston.

Bryson, B. (1990). The Mother Tongue - English And How It Got That Way. London: William Morrow Paperbacks Not in line with IJAES

Chomsky, N. (1972). Language and Mind. New York: Harcourt Brace Jovanovich.

Cruse, D. A. (1995). Lexical Semantics. Cambridge: Cambridge University press.

Crystal, D. (2010). The Cambridge Encyclopedia of Language. Cambridge: Cambridge University Press.

France, P. (2000). The Oxford Guide to Literature in English Translation. Oxford: Oxford University Press.

Fromkin, V., Rodman, R., \& Hyams, N. M. (2007). An Introduction to Language. Boston, MA: Thomson Wadsworth.

Hervey, S., \& Higgins, I. (1992). Thinking Translation: A course in Translation Method: French to English. London: Routledge.

Ibn Yaeesh, A. (2001). Sharh El Mufassal [El-Mufassal Explained]. Beirut: Dar El Kutub Al Ilmiya.

Jasper, D. (ed.). (1993). Translating Religious Texts: Translation, Transgression and Interpretation. University of Glasgow: St. Martin's Press.

Khan, M. M., \& Al Helali, M. (1994). Interpretation of the Meanings of the Noble Quran. Riyadh: Dar-us-Salam. Not in line with IJAES

Lyons, J. (1977). Semantics, Vol. 2. Cambridge: Cambridge University Press. Not in line with IJAES 
Lyons, J. (1981). Language and Linguistics: An Introduction. New York: Cambridge University Press

Nicholson, R. (2008). A Literary History of the Arabs. In T. F. Unwin.,

C. Ogden, \& I. Richards. (1923). The Meaning of Meaning (pp. 660-750). Routledge and Kegan Paul.

Pickthall, M. M. (1999). The Meaning of the Glorious Koran. New York: New American Library

Samirraei, F. (2000). Ma'ani Annahwu [Meaning of Grammar]. Amman: Dar El Fikr lil tiba'a wa nasher wa al tawzee.

Samirraei, F. (2006). Balaghat Al Kalima fi Attabeer Al Qurani [Rhetoric of Words in Quranic expression]. Cairo: Sharikat Al Atek li sinaet El kitab wa tawzee wa Al nasher.

Sapir, E. (1921). Language: An Introduction to the Study of Speech. New York: Harcourt, Brace and company.

Wilkins, D. A. (1972). Linguistics in Language Teaching. London: Edward Arnold. Name is not in line with IJAES

Zipf, G. K. (1965). The Psycho-Biology of Language. Cambridge: Cambridge University Press.

\section{Appendices}

Appendix A

A tabulation of three widely-cited comparative translations of the Holy Quran

\begin{tabular}{|c|c|c|c|}
\hline Source Text & Abdullah Yusuf Ali & $\begin{array}{l}\text { Muhammad Khan } \\
\text { \& Al-Helali }\end{array}$ & Pickthall \\
\hline 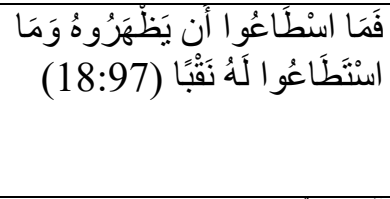 & $\begin{array}{l}\text { Thus were they made } \\
\text { powerless to scale it } \\
\text { or to dig through it. }\end{array}$ & $\begin{array}{l}\text { So they could not } \\
\text { scale it or dig through } \\
\text { it }\end{array}$ & $\begin{array}{l}\text { And (Gog and } \\
\text { Magog) were not able } \\
\text { to surmount, nor } \\
\text { could they pierce (it). }\end{array}$ \\
\hline 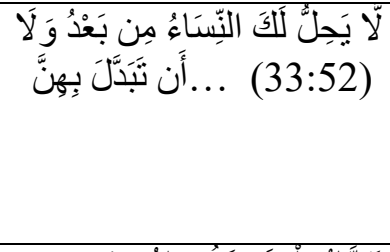 & $\begin{array}{l}\text { It is not lawful for } \\
\text { thee (to marry more) } \\
\text { women after this, nor } \\
\text { to change them for } \\
\text { (other) wives ... }\end{array}$ & $\begin{array}{l}\text { It is not lawful for you } \\
\text { (to marry other) } \\
\text { women after this, nor } \\
\text { to change them for } \\
\text { (other) wives ... }\end{array}$ & $\begin{array}{l}\text { It is not allowed thee } \\
\text { to take (other) women } \\
\text { henceforth nor that } \\
\text { thou shouldst change } \\
\text { them ... }\end{array}$ \\
\hline 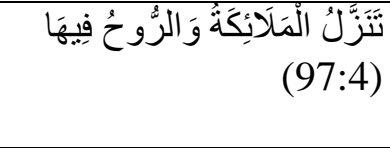 & $\begin{array}{l}\text { Therein come down } \\
\text { the angels and the } \\
\text { Spirit }\end{array}$ & $\begin{array}{l}\text { Therein descend the } \\
\text { angels and the Ruh } \\
\text { (Jibril) }\end{array}$ & $\begin{array}{l}\text { The angels and the } \\
\text { Spirit descend therein }\end{array}$ \\
\hline 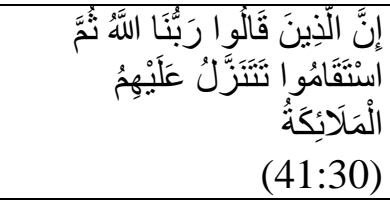 & $\begin{array}{l}\text { the angels descend on } \\
\text { them (from time to } \\
\text { time) }\end{array}$ & $\begin{array}{l}\text { On them the angels } \\
\text { will descend }\end{array}$ & $\begin{array}{l}\text { the angels descend } \\
\text { upon them }\end{array}$ \\
\hline
\end{tabular}

Arab World English Journal for Translation \& Literary Studies 


\begin{tabular}{|c|c|c|c|}
\hline 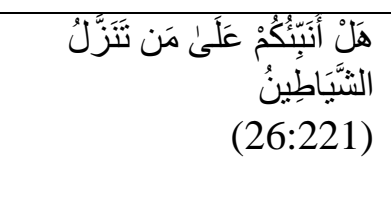 & $\begin{array}{l}\text { Shall I inform you, }(\mathrm{O} \\
\text { people!), on whom it } \\
\text { is that the evil ones } \\
\text { descend? }\end{array}$ & $\begin{array}{l}\text { Shall I inform you, (O } \\
\text { people!), on whom } \\
\text { the devils descend? }\end{array}$ & $\begin{array}{l}\text { Shall I inform you } \\
\text { upon whom the devils } \\
\text { descend? }\end{array}$ \\
\hline 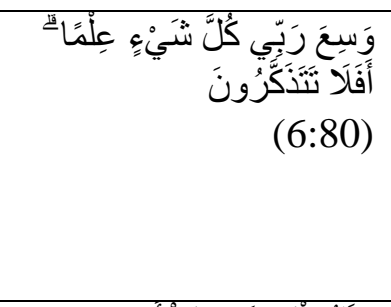 & $\begin{array}{l}\text { My Lord } \\
\text { comprehendeth in His } \\
\text { knowledge all things. } \\
\text { Will ye not } \\
\text { (yourselves) be } \\
\text { admonished? }\end{array}$ & $\begin{array}{l}\text { My Lord } \\
\text { comprehendeth in His } \\
\text { knowledge all things. } \\
\text { Will you not then } \\
\text { remember? }\end{array}$ & $\begin{array}{l}\text { My Lord includeth all } \\
\text { things in His } \\
\text { knowledge: Will ye } \\
\text { not then remember? }\end{array}$ \\
\hline 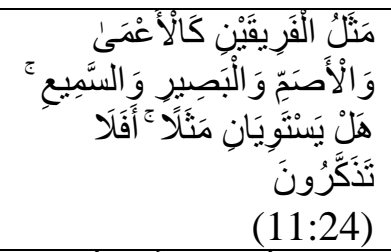 & $\begin{array}{l}\text { Are they equal when } \\
\text { compared? Will ye } \\
\text { not then take heed? }\end{array}$ & $\begin{array}{l}\text { Are they equal when } \\
\text { compared? Will you } \\
\text { not then take heed? }\end{array}$ & $\begin{array}{l}\text { Are they equal in } \\
\text { similitude? Will ye } \\
\text { not then } \\
\text { admonished? }\end{array}$ \\
\hline 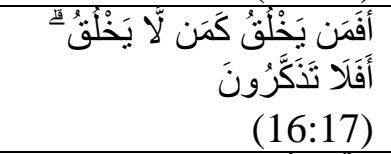 & $\begin{array}{l}\text { Will ye not receive } \\
\text { admonition? }\end{array}$ & $\begin{array}{l}\text { Will you not then } \\
\text { remember? }\end{array}$ & $\begin{array}{l}\text { Will ye not then } \\
\text { remember? }\end{array}$ \\
\hline 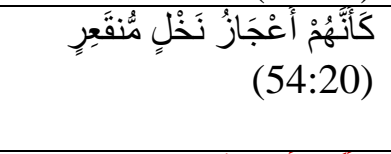 & $\begin{array}{l}\text { as if they were roots } \\
\text { of palm-trees torn up } \\
\text { (from the ground }\end{array}$ & $\begin{array}{l}\text { as though they were } \\
\text { uprooted stems of } \\
\text { date palms }\end{array}$ & $\begin{array}{l}\text { as though they were } \\
\text { uprooted trunks of } \\
\text { palm trees }\end{array}$ \\
\hline 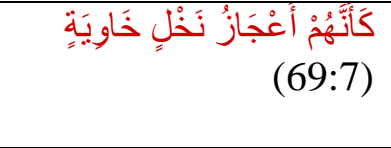 & $\begin{array}{l}\text { as they had been roots } \\
\text { of hollow palm-trees } \\
\text { tumbled down! }\end{array}$ & $\begin{array}{l}\text { as they were hollow } \\
\text { trunks of date palms }\end{array}$ & $\begin{array}{l}\text { as they were hollow } \\
\text { trunks of palm trees }\end{array}$ \\
\hline 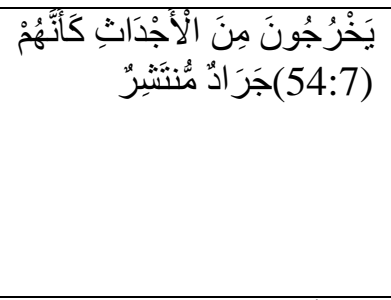 & $\begin{array}{l}\text { They will come } \\
\text { forth,- their eyes } \\
\text { humbled - from (their) } \\
\text { graves, (torpid) like } \\
\text { locusts scattered } \\
\text { abroad }\end{array}$ & $\begin{array}{l}\text { They will come forth, } \\
\text { with humbled eyes, } \\
\text { from (their) graves as } \\
\text { if they were locusts } \\
\text { spread abroad }\end{array}$ & $\begin{array}{l}\text { they come forth from } \\
\text { the graves as they } \\
\text { were locusts spread } \\
\text { abroad, }\end{array}$ \\
\hline $\begin{array}{r}\text { وما أنت بمسمع من في } 135: 22) \\
\text { القبور }\end{array}$ & $\begin{array}{l}\text { But thou canst not } \\
\text { make those to hear } \\
\text { who are (buried) in } \\
\text { graves. }\end{array}$ & $\begin{array}{l}\text { But you can make } \\
\text { hear those who are in } \\
\text { graves }\end{array}$ & $\begin{array}{l}\text { Thou canst not reach } \\
\text { those who are in the } \\
\text { graves. }\end{array}$ \\
\hline 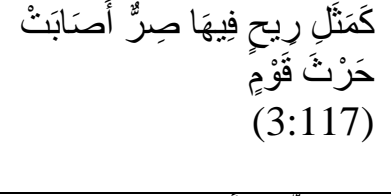 & $\begin{array}{l}\text { likened to a wind } \\
\text { which brings a } \\
\text { nipping frost }\end{array}$ & $\begin{array}{l}\text { The likeness of a wind } \\
\text { which is extremely } \\
\text { cold }\end{array}$ & $\begin{array}{l}\text { as the likeness of a } \\
\text { biting, icy wind which } \\
\text { smiteth } \\
\text { the harvest of a people }\end{array}$ \\
\hline 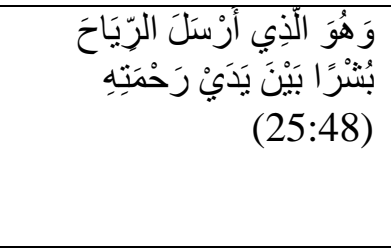 & $\begin{array}{l}\text { And He it is Who } \\
\text { sends the winds as } \\
\text { heralds of glad } \\
\text { tidings, going before } \\
\text { His mercy }\end{array}$ & $\begin{array}{l}\text { It is He Who sends the } \\
\text { winds as heralds of } \\
\text { glad tidings }\end{array}$ & $\begin{array}{l}\text { And He it is Who } \\
\text { sendeth the winds, } \\
\text { glad tidings heralding } \\
\text { His mercy }\end{array}$ \\
\hline
\end{tabular}


AWEJ for Translation \& Literary Studies Volume, 5 Number 2. May 2021

\begin{tabular}{|c|c|c|c|}
\hline 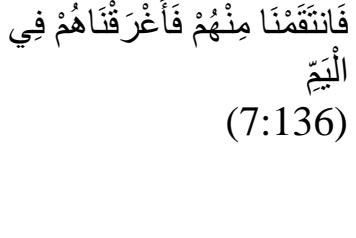 & $\begin{array}{l}\text { So We exacted } \\
\text { retribution from them: } \\
\text { We drowned them in } \\
\text { the sea }\end{array}$ & $\begin{array}{l}\text { So We took } \\
\text { retribution from them. } \\
\text { We drowned them in } \\
\text { the sea. }\end{array}$ & $\begin{array}{l}\text { Therefore We took } \\
\text { retribution from them; } \\
\text { therefore } \\
\text { drowned them in the } \\
\text { sea: }\end{array}$ \\
\hline 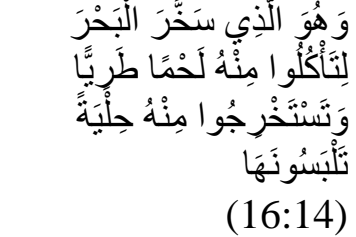 & $\begin{array}{l}\text { It is He Who has } \\
\text { made the sea subject, } \\
\text { that ye may eat } \\
\text { thereof flesh that is } \\
\text { fresh and tender }\end{array}$ & $\begin{array}{l}\text { And He it is Who has } \\
\text { subjected the sea (to } \\
\text { you) that you eat } \\
\text { thereof fresh tender } \\
\text { meat (fish)... }\end{array}$ & $\begin{array}{l}\text { And He it is Who hath } \\
\text { constrained the sea to } \\
\text { be of service that ye } \\
\text { eat fresh meat from } \\
\text { thence }\end{array}$ \\
\hline
\end{tabular}

